\title{
Buya and religious issues in the 2019 presidential election in West Sumatra
}

\section{Buya dan isu agama pada pilpres 2019 di Sumatera Barat}

\author{
Adlin \\ Government Study, Faculty of Social and Political Sciences, Universitas Riau \\ Address: Kampus Bina Widya KM. 12.5, Simpang Baru, Tampan, Pekanbaru, Riau Province, \\ Indonesia 28293 \\ E-mail: adlin@lecturer.unri.ac.id
}

Article History: Received 29 May 2021; Accepted 08 December 2021; Published Online 08 February 2022

\begin{abstract}
This article attempts to explain the influence of buya and religious issues on Jokowi's vote decline in the 2019 Presidential Election (Pilpres) in West Sumatra. In the 2014 Presidential Election, Jokowi, who was paired with Jusuf Kalla, received 23.1 percent of the vote. However, in the 2019 Presidential Election, the vote share for Jokowi, who was paired with Ma'ruf Amin, fell to 14.1 percent. Ahead of the 2019 Presidential Election, there was a conflict between the buya in West Sumatra and Jokowi's supporters regarding religious issues. This study used qualitative methods by relying on documentation studies related to the influence of the buya and religious issues ahead of the 2019 Presidential Election in West Sumatra. The study's findings indicate that the buya and the majority of the people in West Sumatra practice modern Islam, while the vice-presidential candidate KH. Ma'ruf Amin practices traditional Islam. Religious issues in the form of the Islam Nusantara concept and the Sharia Regional Regulation (Perda) sharpen the difference between the buya and voters in West Sumatra with the JokowiMa'ruf pair. It affected the defeat of Jokowi-Ma'ruf in West Sumatra in the 2019 Presidential Election.
\end{abstract}

Keywords: Buya; presidential election; religious issues

\begin{abstract}
Abstrak
Artikel ini mencoba menjelaskan pengaruh isu buya dan agama terhadap penurunan suara Jokowi pada Pemilihan Presiden (Pilpres) 2019 di Sumatera Barat. Pada Pilpres 2014, Jokowi yang berpasangan dengan Jusuf Kalla memperoleh 23,1 persen suara. Namun, pada Pilpres 2019, perolehan suara Jokowi yang berpasangan dengan Ma'ruf Amin turun menjadi 14,1 persen. Jelang Pilpres 2019, sempat terjadi konflik antara buya di Sumatera Barat dengan pendukung Jokowi terkait isu agama. Studi ini menggunakan metode kualitatif dengan mengandalkan studi dokumentasi terkait pengaruh buya dan isu agama jelang Pilpres 2019 di Sumatera Barat. Temuan studi menunjukkan bahwa buya dan mayoritas masyarakat di Sumatera Barat menganut Islam modern, sedangkan calon wakil presiden KH. Ma'ruf Amin mempraktikkan Islam tradisional. Isu keagamaan berupa konsep Islam Nusantara dan Peraturan Daerah Syariah (Perda) mempertajam perbedaan buya dan pemilih di Sumatera Barat dengan pasangan Jokowi-Ma'ruf. Hal itu berimbas pada kekalahan Jokowi-Ma'ruf di Sumatera Barat pada Pilpres 2019.
\end{abstract}

Kata kunci: Buya; pemilu presiden; isu agama

\section{Introduction}

This article attempts to clarify the relationship between Buya Gazahar and a number of buya who support him, as well as religious issues with the massive defeat of candidate number 1 Jokowi-Ma'ruf in 2019 Presidential Election in West Sumatra Province. In this province, Jokowi's strategy of collaborating with the ulama as his representatives to gain the support of the ulama and the majority of Muslim voters did not work as expected. Indeed, Jokowi's strategy of partnering with the highest leader of the Indonesian Ulema Council (MUI) was intended to counter religious issues and gain support from the majority of Muslim voters (Temby 2019). Although Jokowi collaborated with the central MUI leader, KH Ma'ruf Amin, the vote acquisition in the 2019 Presidential Election was even lower than the 2014 Presidential Election. In the 2014 Presidential Election results, Jokowi's pair, Jusuf Kalla, who was not an ulama, 
were able to receive 23.1 percent of the votes. However, in the 2019 Presidential Election, Jokowi's pair, Ma'ruf Amin, who is an ulama, dropped to 14.1 percent (Putra 2019). Jokowi initially received 539,308 votes in 2014 but fell to 407,761 votes in 2019. Meanwhile, Prabowo's vote acquisition rose by 691,228 so that Prabowo's victory in West Sumatra rose to 1,098,989 votes (Hakim 2019).

Religion is a sensitive issue for the Minangkabau community, which has always been addressed by the MUI of West Sumatra. MUI is a council that has even been at the forefront of organizing social movements to fight for the people's religious aspirations ahead of the 2019 Presidential Election. The rejection of the MUI of West Sumatra and Islamic mass organizations against the plan to build the Siloam Hospital in Padang City in 2013 was one of the examples of its movements. This refusal was linked to the existence of the Siloam Hospital as an agent of Christianization of Muslims and the people of West Sumatra's previous traumatic experiences as a result of Christianization. Because of these factors, people try to avoid having the same terrible experience again (Zulfadli \& Arrasuli 2017). The refusal was not only intended against the establishment of the hospital but also the entire investment of the Lippo Group Tbk company, which was carried out in an organized way by the central figure of the MUI of West Sumatra. As a result, all of the company's activities were stopped (Hospita et al. 2018). Therefore, it can be seen that the West Sumatran are relatively in agreement with the buya and can unite to fight against particular parties related to religious issues.

In some countries, religious leaders have been shown to be able to influence voter choices in elections. Freedman (2020) discovers the crucial role played by religious institutions of Rabbi groups in driving voters to religious parties in local politics in Israel. Alava \& Ssentongo (2016) argued that in the 2016 parliamentary and Presidential Elections in Uganda, many religious leaders actively or tacitly supported the incumbent regime. Religious leaders also spoke out and encouraged political action thereby increasing the space for public debate. Bøås et al. (2019) revealed that in the 2013 Presidential Election in Mali, there was a clear consensus between religious leaders and Ibrahim Boubacar Keita (IBK) because they were seen as capable of bringing Mali out of the crisis, restoring Mali's territorial integrity, and eradicating corruption. Ashsubli et al. (2021) believed that religious figures like Ustadz Abdul Somad are indeed influential as vote-getters in the 2019 Presidential Election in Indonesia. In the LSI survey, Denny JA positioned Ustadz Abdul Somad as a religious figure whose appeals are heard by most voters.

Religious leaders might influence voters because they are role models in society. Religious leaders, according to Schliesser (2020), are role models for the community. As moral authorities, they act as influencers by shaping social values. They do not seek their gain, but rather by the goal of religious leaders being trusted and credible in the eyes of their followers. Akinloye (2018) also found that between 1999 and 2015, religious leaders had a strong influence on their followers in Nigeria. People trust religious leaders' opinions more than political figures regarding politics in elections.

A number of literature studies also write that religious issues are also used by religious leaders and political actors to influence voter choices in elections. Guth et al. (2006) stated that the issue of religion raised by the republican and democratic parties influenced voters' choice in choosing the president of the United States in 2004. Each voter who is affiliated with traditional and modern religious sects in America has certain political views on religious issues. Religious issues have been used by political parties to mobilize voters to choose their candidates. It was found that religion issues and voter evaluation of Bush's performance of the republican candidate regarding religion in the previous period had contributed to the Republican party's victory in the region that determined the victory of the 2004 Presidential Election. According to Guth et al. (2005), the variable of religion has a considerably decisive outcome of the election than that of gender and other characteristics. Raymond (2018) argued that religious issues articulated by political parties might result in the polarization of religious-affiliated supporters. When parties compete on relevant issues to religious voters who maintain organizational ties with religious groups in society, the polarization effect due to religious issues will strengthen and determine the outcome of the vote. Some scholars believed that Trump's victory in the 2016 American 
Presidential Election was also related to the strengthening of several issues, including religions. BarrettFox (2018) found that Trump's victory in the 2016 American Presidential Election was associated with Trump's ability to invite conservative Christians to gain the power to protect their Christian hegemony in America. This has a real impact on the widespread support of conservative Christians for Donald Trump in the 2016 American Presidential Election.

Several studies outside the United States regarding voting behavior have also found that religious values affect voter preferences for choosing particular political parties or presidential candidates. Goldberg's study on Swiss society revealed that religious values were the key determinant of voters' choice of political parties. It is indicated by the significant positive relationship between Catholic voters and their choice of the Catholic Democratic Party (CVD) (Goldberg 2014). Jeppsonn's (2018) study in Sweden demonstrated that religious issues for some voters have remained a voter preference in making political choices since 1986-2016. Agbor's research also found that religion, particularly strict religious observance is a determining factor in voter choice in elections in Nigeria. The influence of religious leaders and the religious flow of voters consistently influences voter elections in the 20112015 and 2019 elections in Nigeria (Agbor 2019). In the 2015 Nigerian Presidential Election, Religion was used to organize voter support, for example, by publishing religious sentiment issues in order to obtain a benefit in the general election (Onapajo 2016). Likewise, voters in Nigeria consider religion in determining a presidential candidate in Nigeria in 2019. The candidate to be chosen is thought to be more secure in terms of religious and worship freedom (Agbor 2019).

Religious issues in competitions of general elections are also found in several Muslim-dominated countries on the Asian and the African continents, including Indonesia (Makhasin 2017). In order to minimize religious issues in the Presidential Election, Jokowi appointed Ma'ruf Amin as his deputy candidate because Maruf Amin is an influential ulama figure among Muslims as he serves as chairman of the Indonesian Ulema Council and Rais Am Nahdlatul Ulama. Therefore, he is expected to attract the votes of people affiliated with Nahdlatul Ulama (NU) and other Muslims (Sanusi \& Gumilar 2019). NU is claimed to be one of Indonesia's largest social organizations (Sujono 2021). As a result, Maruf Amin, as a powerful ulama, will be utilized as a decoy for religious concerns that political opponents may use against Jokowi, among other considerations (Saputro 2018). In the 2019 Presidential Election, Ma'ruf Amin brought up religious issues associated with traditional Islam. His role was not solely related to the Presidential Election but further, the struggle to protect the ideology of Ahlussunnah Wal Jamaah from the threat of Hizbut Tahrir Indonesia and the Wahhabi sect linked to the Prabowo-Sandi pair (Temby 2019).

Previous studies have demonstrated that church leaders' recommendations can influence their congregations' political decisions, which can have an impact on their sect or denomination, as evidenced by concrete voting actions in many nations, including the United States (Torgler et al. 2013). In Islam, buya or ulama recommendations were proven to influence voter preferences in the general election. The importance of the ulama in influencing voter choice was evident in the elections following the fall of the New Order Era, as evidenced by the ulama assembly's decision in the 1999 election to encourage Muslims to vote for Muslim legislative candidates. In addition, a fatwa was issued in 2009 outlawing non-voting and activities with a similar purpose (As'ad 2011). In the 2014 Presidential Election, some ulama also issued a fatwa for Muslims to not vote for particular candidates. While at the same time, they support and are affiliated with other candidates (Winarni 2014). Ulama or tuan guru in West Nusa Tenggara, as well as buya in West Sumatra, and kiai in Java continue to have a considerable influence on local voting behavior. The community still follows the guidance of the ulama as indicated by the strong community support for Muhammad Zainul Majdi (Tuan Guru Bajang) who was elected as Governor of West Nusa Tenggara (Oktara 2015).

Some scholars are indeed actively involved in winning candidates in general elections in Indonesia. In the 2004 Presidential Election, the kiai had a significant part in encouraging people to vote for a candidate for a national leader. This is accomplished in a variety of ways, including: (1) providing statements 
of support to certain candidates through the media and frequently even conveying them in advance through the recitation and istighosah assemblies, (2) suggesting that santri at the Islamic boarding school (pesantren) convey to their respective families to choose candidates who are supported by the kiai, (3) providing opportunities for candidates to attend their pesantren, (4) issuing fatwas supporting particular candidates based on the Qur'an, Hadith, and other traditional books, (5) consolidating kiai to strengthen candidate support, (6) joining the candidate's campaign team, (7) mobilizing the masses with the support of their students to become supporters of specific candidates (Noeh \& Othman 2012). Because kiai Ma'ruf Amin was Jokowi's partner, most of kiai of NU fully support Jokowi-Ma'ruf in the 2019 Presidential Election (Temby 2019).

The separation of ulama and voters in terms of political preference is inextricably linked to the typology of Indonesia's Islamic movement, which is divided into two main poles, traditional Islam and modern Islam. In 1980, Noer (1996) discovered that the modern Islamic movement in the archipelago was centered on these two poles, based on his research. The distinction can be viewed in three ways: The first is the role of the spirit in purifying religious beliefs. This mindset has become the driving force behind current Islamic movements that continue to call for an end to the practice of superstition, bid'ah, and khurafat among Muslims. Traditional Muslims, on the other hand, consider traditional religious activities as a reaction to modern Muslims' efforts to defend their practices with superstition, bid'ah, and khurafat. Second, sectarian disputes are mostly due to fiqh concerns. Differences in attitudes toward fiqh issues eventually lead to differences of opinion and fanatical attitudes toward the group. Third, the perspective of what is meant by change and rational thinking. Traditional Muslims are thought to embrace the status quo, which implies they wish to keep Islamic traditions and do not want new developments to emerge. Modern Muslims, on the other hand, regard religious tradition changes to be significant and necessary (Imadudin 2005).

Discussions concerning traditional Islam-modern Islam can be identified through the actions of the movement. On the social dimension, traditional Muslims are represented by NU and Persatuan Tarbiyah Islamiyah (Perti). NU supporters are largely based in Java, while Perti is growing rapidly in Sumatra. Modern Islamic groups are associated with Muhammadiyah, Al-Irsyad, Persatuan Islam (Persis), and others. In the political sphere, in the Old Order era, NU and Perti were political platforms of traditional Islamic groups; while the Indonesian Muslim Syuro Council (Masyumi) and the Indonesian Islamic Syarikat Party (PSII) were organizations that fight for modern Islam (Imadudin 2005). Therefore, as Ma'ruf Amin from Nahdlatul Ulama (NU) was appointed as a candidate for Jokowi's vice president, of course, it will be difficult to attract the masses from modern Islamic groups with different views on matters of worship and politics.

In the context of Minangkabau society, Islam that has long been established is modern Islam. Modern Islam has been grounded in the identity of the community. This modern Islamic concept has become the norm that serves as the guideline and standard of truth in society and has penetrated into aspects of Minangkabau society's life (Erman 2015). Modern Islam is distinguished by its aim of renewing Islamic thought by returning to the authenticity of Islam based on the Qur'an and Sunnah, rather than inventing or introducing something new (Razzaq 2014). One of the modern Islamic organizations is Muhammadiyah, which also intends to purify the practice of Islam which has been mixed up with superstition, bid'ah, and khurafat (Suwarno 2019). The establishment of modern Islam in West Sumatra in line with the rapid progress of Muhammadiyah was developed by Karim Amrullah. His thoughts are in line with KH. Ahmad Dahlan, the founder of Muhammadiyah, because they were both disciples of Sheikh Khatib Al Minangkabauwi and studied together in Mecca, Saudi Arabia (Bahtiar 2019). Politically, modern Muslims will support the struggle to realize Islamic teachings and Islamic law to individuals, society, and the state (Sonhaji \& Maulida 2020). Therefore, the understanding of Muslim voters who developed in West Sumatra with modern Islam is different from that of KH. Ma'ruf Amin joined Nahdlatul Ulama that has traditional Islamic ideology. 


\section{Research Method}

This study employed a qualitative method approach. It adopted the work of Xiao and Watson, while the framework used as a guideline for the qualitative implementation of the systematic review was the thematic synthesis method as described by Thomas and Harden. This procedure consists of three primary stages, including: preparation, screening and validation, content review, and synthesis and reporting (Thomas \& Harden 2008). The major references used were articles in scientific journals that discuss religious leaders, religious issues, and general elections.

Other documents used as data sources included articles from internet websites originating from national and local online media that provide an explanation of buya and political and religious issues in West Sumatra in the 2019 Presidential Election. The data collected were then analyzed using theories and previous studies so that a synthesis was produced according to the analytical steps proposed by Xiao \& Watson.

\section{Results and Discussion}

\section{History of the voice base of modern Islamic political parties in West Sumatra}

If the elections are held in a democratic environment, West Sumatra will be the basis for the votes of Islamic political parties, particularly modern Islamic political parties. People in West Sumatra voted for the Masjumi Party in the 1955 General Election, which was a modern Islamic political party dedicated to implementing Islamic teachings and laws in the lives of individuals, communities, and the Republic of Indonesia towards the pleasure of Allah. This support also has the characteristic of rejecting the teachings of communism by considering the teachings to be kufur (Sonhaji \& Maulida 2020). In the 1955 General Election, West Sumatra, which was part of Central Sumatra, was allocated 11 seats covering 13 districts, including: Agam, Batang Hari, Bengkalis, Indragiri, Kampar, Kepulauan Riau, Limapuluh Kota, Merangin, Padang Pariaman, Pasaman, Pesisir Selatan/Kerintji, Sawah Lunto, Solok, Tanah Datar and two cities, Bukit Tinggi and Padang Cities. In the 1955 general election, the modern Islamic party group, Masjumi, won 51 percent of the valid votes, thus securing 6 seats. NU as the traditional Islamic party, received only $5 \%$ of the vote and thus did not secure a seat. Meanwhile, 3 seats were secured by Perti after receiving 22 percent of the votes, 1 seat for PKI, and 1 seat for PPTI (Pemilu Asia 2009).

Furthermore, the election results at the beginning of the Reformation order show that the majority of voters in West Sumatra also chose Islamic parties. In the 1999 national legislative elections, Islamic parties won 57 percent of the seats in the national legislature with the majority of modern Islamic parties such as the Partai Amanat Nasional (PAN) receiving 22 percent of the votes and getting 3 seats, the Partai Bulan Bintang (PBB) receiving 6 percent and getting 1 seat, and Partai Keadilan receiving 3 percent and getting 1 seat. Meanwhile, the Partai Persatuan Pembangunan (PPP), which follows a traditional Islamic structure, won 21 percent and got 3 seats. Then, the nationalist parties received 43 percent of the seats as gained by the Partai Golongan Karya (Golkar) for 23 percent and got 4 seats and the Partai Demokrasi Indonesia Perjuangan (PDIP) for 10 percent and got 2 seats (Pemilu Asia 2009). Likewise, in the 2004 elections, Islamic parties again received 64 percent of the vote, with the modernist Islamic parties such as PAN, PKS, and PBB each receiving 2 seats while traditional Islamic parties such as PPP receiving 2 seats and the Partai Bintang Reformasi (PBR) receiving 1 seat. Meanwhile, the nationalist parties received 36 percent of the seats, including the Golkar Party with 4 seats and the Democrat Party with 1 seat. In this election, the PDI-P did not win a seat, despite winning two seats in the last election. Moreover, what is quite interesting is that PBR, which is based on Islamic mass, only managed to win one seat (Ranahberita.com 2013).

Slightly different outcomes occurred in the results of the 2009 and 2014 national legislative elections in West Sumatra with Islamic political parties losing seats to nationalist political parties. According 
to the results of the 2009 national legislative elections in West Sumatra, Islamic parties received only 43 percent of the seats in the national legislature in West Sumatra. However, in the context of Islamic parties, modernist Islamic parties continue to hold the majority, with PKS winning 2 (two) seats and PAN winning 2 (two) seats. Meanwhile, traditional Islamic parties like PPP only won 1 seat. Meanwhile, the Partai Kebangkitan Bangsa (PKB) did not get a seat in the DPR because it only collected 2 percent of the vote (KPU 2009, Ditpolkom Bappenas 2009). On the other hand, the nationalist parties received 57 percent of the seats, with the Democratic Party winning 5 seats and the Golkar Party winning 3 seats (Detiknews 2009). Likewise, the results of the 2014 national legislative elections show that Islamic parties only received 36 percent of the seats in the national legislature in West Sumatra. The modern Islamic party such as PKS won 2 seats while PAN won 1 seat. Meanwhile, the traditional Islamic parties like PPP received 2 seats. Then, the nationalist parties received 64 percent of the seats, with the Gerindra Party, the Democrat Party, the Golkar Party, the PDIP receiving 2 seats each, and Nasdem Party receivingd 1 seat (Suryani 2014).

West Sumatra as the mass base of modern Muslims is again seen in the results of the 2019 legislative elections which were held concurrently with the 2019 Presidential Election. While political parties that support Prabowo-Sandi were aligned with ijtima ulama, nationalist parties continue to earn large votes. The aggregate votes for political parties supporting ijtima ulama were 64 percent of the seats in the DPR RI. Among them, the Gerindra Party and PAN each received 3 quotas for DPR RI members, the Partai Keadilan Sejahtera and the Democrat Party both also won 2 quotas for DPR RI members. Meanwhile, political parties supporting Jokowi-Ma'ruf won 36 percent of the DPR RI seats, including the Partai Golongan Karya with 2 seats, NasDem with 1 seat, and PPP with 1 seat (Kumparan News 2019). Meanwhile, PDIP as the major supporter of the Jokowi-Ma'ruf pair did not win a seat in the DPR RI, implying that this party lost the 2 seats they got in the 2014 legislative election (Saputra 2019).

\section{Expansion of support of modernist Islamic ulama to regions ahead of the 2019 presidential election}

In the 2019 Presidential Election, there was polarization in the support of the ulama at the national level, which was between the support of pro ijtima ulama, most of whom came from the Modern Islamic group that supports the Prabowo Subianto-Sandiaga Uno (Prabowo-Sandi) pair and the majority of counterijtima ulama from the traditional Islamic group that supports the Jokowi-Ma'ruf Amin pair. Ahead of the 2019 Presidential Election, pro-ijtima ulama conducted two meetings that ultimately agreed to support Prabowo-Sandi in the 2019 Presidential Election. A total of 17 points of mutual agreement between Prabowo-Sandi and ulama fueled the enthusiasm of supporters to realize Prabowo-Sandi's victory. The supporters even were willing to turn their homes into bases for the Prabowo-Sandi support team (Priatmojo \& Sadat 2018). This difference in political direction repeats the direction of political support following the 1955 election. The Masjumi Party with the modern Islamic wing was tough on the PNI and PKI and stood in opposition to the Old Order government. This was represented in the 2019 Presidential Election by pro-ijtima ulama. On the other hand, NU that tended to compromise with the PNI and PKI in support of the Old Order government was represented in the 2019 Presidential Election by ulama against ijtima (Sonhaji \& Maulida 2020).

The group of ulama who support Prabowo-Sandi was those who coordinated the 212 Action demanding Ahok be punished for blasphemy against Islam. They were members of the 212 Action Brotherhood (Persaudaran Aksi 212) and the National Movement of Defender of Ulama's Fatwa (Gerakan Nasional Pembela Fatwa Ulama) with many actors like Slamet Maarif and others joining the Prabowo-Sandi National Winning Body (BPN) (CNN Indonesia 2019). A survey conducted by the institute of Konsep Indonesia shows the support for community organizations (ormas) that favors the two presidential candidates. The Prabowo-Sandi pair received greater support than Jokowi-Maruf from three Islamic organizations, including the Persatuan Islam (Persis), the Islamic Defenders Front (FPI), and Alkhairaat (Astungkoro \& Saubani 2019). 
The pro-ijtima ulama group supported the Prabowo-Sandi pair for a number of reasons because the pair (1) received the support of the ulama in the ijtima ulama, (2) was more loyal to Pancasila and the 1945 Constitution, thus protecting religion and the Unitary State of the Republic of Indonesia (NKRI), (3) was committed to agreeing on an agreement with the ulama, (4) glorifying religious leaders and rejecting negative behavior towards religious leaders, (5) supporting the development of civilization based on religion and not discriminating religions, (6) intelligent and could prevent conflicts between citizens, (7) being considered honest and trustworthy in protecting citizens, (8) rejecting the rise of the Partai Komunis Indonesia (Indonesian Communist Party), Islamic liberalism groups, deviant sects, and immoral behavior, (9) more prepared to win and to lose and not cheating in elections, (10) was considered to bring Indonesia to be prosperous (Lazuardi 2019).

The 212 movement, which was spearheaded by the pro-ijtima ulama, had a greater influence due to dissatisfaction with blasphemy against Islam. Discrimination against the ulama has had a significant impact on political choices at all levels, from the national to the local. The Muslim-led 212 movement is not just a phenomenon that occurs in Java Island. In the Provinces of West Sumatra, North Sumatra, South Sulawesi, and North Sulawesi, the 212 influential narratives also influence voters who practice Islam in the regions in making decisions (Nubowo 2020). The appointment of Ma'ruf Amin as Jokowi's deputy was not enough to improve Jokowi's credibility in the eyes of ulama and Islamic community organizations, particularly Perti and Muhammadiyah in West Sumatra and South Sulawesi. Moreover, conservative voters argue that following the ijtima ulama is an obligation. In line with this view, they believe that defeating Jokowi-Ma'ruf was a religious obligation (Nubowo 2020).

In the perspective of pro-ijtima ulama and their supporters from the national to the local level, Jokowi's policies are considered discriminatory against ulama and Muslims (Siregar 2019). During Jokowi's time, religious leaders who opposed government projects were prosecuted. On the other hand, blasphemers of Islam were offered tremendous defenses. When religious leaders demanded that the law be obeyed, they were persecuted, criminalized, and labeled as rebels, and their human rights are violated (Saputra \& Alfath 2017). Jokowi and his supporting parties were also considered anti-Islamic parties and supported the rise of the Indonesian Communist Party (Thalib 2018). An example was the police determining the status of FPI ulama, Habib Rizieq Shihab, from witness to suspect, in an indecent chat case involving a woman with the initial of FZ (Saputra \& Alfath 2017). Another example was the police detaining Zulkifli Muhammad Ali and establishing the status of a suspect in cases of hate speech and racial discrimination in his da'wah (Riana \& Chairunnisa 2018). Furthermore, Jokowi was seen as skeptical by hard-line Islamic organizations and he had also disbanded conservative groups such as Hizbut Tahrir Indonesia (HTI) (Wanto 2020). President Jokowi, on the other hand, denies that his government has criminalized ulama. On June 25, 2017, Jokowi met with Bachtiar Nasir, the leader of the National Movement to Support the MUI Religious Edict (GNPF-MUI), and indicated that he did not agree he was oppressing or discriminating against Muslims. According to Bachtiar Nasir and the GNPF-MUI, however, society has already stamped Islam as intolerant, anti-diversity, and anti-Pancasila (Bentengsumbar 2017). Jokowi insisted that he did not discriminate against ulama and claimed that it was just an issue (Sani \& Hantoro 2019).

This political situation has made the ulama and the people of West Sumatra, who are predominantly modern Muslims, were more likely to support Prabowo-Sandi compared to Jokowi-Ma'ruf. Following the 'ijtma ulama II's decision to support Parabowo-Sandi, the West Sumatran National Movement to Protect Ulama Fatwa (GNPF Ulama) moved quickly to put the Prabowo-Sandi pair's declaration into action in West Sumatra as a concrete form of support for the ulama consensus that had decided to support Prabowo-Sandi (Sumbarfokus 2018). The support of modernist Islamic ulama in West Sumatra is getting stronger as evidenced by the involvement of ulama from the elements of GNPF Ulama of West Sumatra in the national campaign of the Prabowo-Sandi pair in Padang City. On this occasion, the head of the GNPF Ulama of West Sumatra ordered Parabowo-Sandi volunteers to stand by until April 17, 2019, to guard Prabowo Sandi's victory in West Sumatra. 
This finding is in accordance with the phenomenon proposed by Bøås et al. (2019) that religious leaders are actively involved in making consensus with presidential candidates and even openly provide support to presidential candidates who are considered more capable. Alava \& Ssentongo (2016) stated that religious leaders are vocal where they can encourage political action in favor of particular candidates. Likewise, Freedman (2020) argued that religious leaders in religious institutions play the role of encouraging voters to support certain candidates. These statements are strengthened by Ashsubli et al. (2021) who found that religious figures were indeed influential as vote-getters in the 2019 presidential election in Indonesia.

\section{Buya's resistance to religious issues ahead of the 2019 presidential election}

The perception that Jokowi and his supporters are a group that seeks to blaspheme Islam and a party that must be fought is growing stronger in the view of Buya and the people of West Sumatra ahead of the 2019 Presidential Election. Criticisms of the Indonesian Solidarity Party (PSI), a pro-Jokowi party, condemning Regional Regulations based on Islamic Sharia (Sharia Perda), elicited a hostile response in West Sumatra because West Sumatra is indeed an area that implements Sharia Perda. Sharia Regulations in various regencies and cities in West Sumatra also emerged from the initiatives of the community and the buya in West Sumatra. The first Sharia Regional Regulation was the Regional Regulation in Solok Regency Number 10 of 2001 which contained the obligation for school students and persons planning to marry to recite the Qur'an (Tempo 2011). According to Lakspesdam of NU data, until 2011, there were 25 sharia regulations in West Sumatra, for example, it is mandatory to recite the Qur'an, to cover aurat when dressing up, manage zakat, and forbid indecent activities (Tempo 2011). Pisani \& Buehler (2016) wrote that Sharia Regional Regulations continue to develop in Indonesia and West Sumatra becomes the second largest province issuing 54 Sharia Regional Regulations (Hasan 2018).

Therefore, the statements of PSI's chairman, Grace Natalie, of rejecting the existence of Sharia Regional Regulations in Indonesia, was opposed by West Sumatran ulama. Buya Gazahar, Chair of the MUI of West Sumatra, stated firmly that it is illegal to support political groups or people who are considered rejecting the Sharia regulation by political groups. (Nathaniel 2019). According to some experts, PSI's position against religious regulations can affect the level of electability of the party as well as the presidential candidates supported by this party (Nurita 2018). Meanwhile, PSI did not want to retract its statements and even seemed adamant with the statements by emphasizing that they were ready to accept all the consequences of their attitude towards rejecting the Sharia Regional Regulations (Nurita 2018). Buya Gazahar stated that Jokowi-Ma'ruf would lose money because PSI was brought against the Sharia regulation (Nathaniel 2019). According to Gazahar, the results of the 2014 Presidential Election show that the majority of people with the right to vote in Minangkabau support Prabowo Subianto over Jokowi. At that time, PSI was a supporting party but not endorsing Jokowi. As a result, PSI's attitude is believed to affect Jokowi's vote acquisition in the 2019 Presidential Election (Nathaniel 2019).

Another sensitive issue raised by the Jokowi-Ma'ruf pair is the desire to support the application of the Islam Nusantara concept throughout Indonesia, including West Sumatra. The idea of Islam Nusantara which was generated at the 33rd NU congress in Jombang is an alternative interpretation of the Arab world of Islam. Furthermore, the idea was disseminated in Indonesia and abroad by the NU mass organizations. Islam Nusantara is described as an Islam that values peace, tolerance, friendliness, noble behavior, and the avoidance of violence (Suriyanto 2015). The idea of Islam Nusantara received support from Ma'ruf Amin even he considers the Islam of the Indonesian Ulema Council (MUI) as Islam Nusantara which became the umbrella for all parties (Alfons 2018). Ma'ruf Amin even was ready to make Islam Nusantara a campaign jargon (Dahono 2018).

However, the idea of Islam Nusantara was rejected by the buya who were part of the MUI of West Sumatra, including in the districts and cities in West Sumatra. They asserted that this region did not need the concept of Islam Nusantara or any other attributes following the word 'Islam'. The word 'Islam' as 
seen by modern Muslims is already perfect (Cahyono 2018). Modernist Islam's viewpoint necessitates renewal, which entails a return to the validity of Islamic teachings based on the Qur'an and Sunnah, as well as a refusal to construct or add anything new to Islamic teachings (Razzaq 2014). As a result, it's only natural that the West Sumatra Modernist Islamic community opposes the concept of Islam Nusantara, which they believe adds something new to Islam.

There are 7 arguments against Islam Nusantara put forward by the MUI of West Sumatra, including: (1) Islam Nusantara incites pointless arguments and may lead to misunderstanding of Islamic principles, (2) the composition of the Indonesian language shows limitation on Islam in certain areas, which is the "Nusantara". This has an impact on the diminishing and narrowing of the concept of Islam which should be a mercy for the universe and all humans, (3) if the narrative "Islam Nusantara" is interpreted as washatiyah friendliness, tolerance, and others, it is not characteristic of Islam in some locations, but it is a basic value that has become the privilege ('munazziyat') of Islamic teachings (4) "Wasathiyah" and others that are considered characteristics of "Islam Nusantara", are actually merely a subset of the privileges of Islamic teachings that are inextricably linked to other privileges, including rabbaniyyah divineyyah, syumuliyyah, mumayyizat. Therefore, the presence of Islam Nusantara will only cause Islam to become imperfect, (5) if "Islam Nusantara" is interpreted as a way to invite people to religion referring to the Wali Songo style in Java, this undoubtedly dwarfs religious leaders' efforts to build Islamic teachings outside Java through a variety of $d a$ 'wah strategies, (6) if the cultural approach is considered as a unique feature of "Islam Nusantara" it should not be monopolized by "Islam Nusantara" itself, because the buya in West Sumatra accommodated this cultural approach, emerging a collective agreement, which is the "Oath of Sati Marapalam" whose philosophy has served as the guideline for the Minangkabau people until now, namely the Basandi Syarak custom, the Kitabullah Basandi Syarak. Even though they have achieved an agreement and are directed and rooted in people's lives, there is no need to include the term Islam in West Sumatra, for example, "Islam Minang". (7) If "Islam Nusantara" is regarded as tolerant Islam that rejects radicalism, then such thinking obviously accuses Islam of being the cause of radicalism and violent acts. Based on the considerations above, the MUI and MUI districts/cities throughout West Sumatra do not hesitate to make the statement that "Islam Nusantara" is unnecessary in Minang land because Islam is perfect and does not require any modifications in the form of terminology (Damarjati 2018).

Furthermore, the debate heated up because Ma'ruf Amin and his supporters at the central MUI remained firm on the concept of Islam Nusantara, as well as the buya at the West Sumatran MUI were adamant in their opposition to the term Islam Nusantara. Ma'ruf Amin even chastised and reminded the MUI of West Sumatra to obey the Central MUI regarding the notion of Islam Nusantara (Alfons 2018). According to Ma'ruf Amin, MUI should not have a negative image of certain sects because MUI is a forum for all sects, except heretical ones (Prasetia 2018). This is consistent with his commitment as a Nahdlatul Ulama who obviously will develop Islam Nusantara (Dahono 2018). Buya Gazahar and his supporters in West Sumatra, on the other hand, continue to oppose those who accept the idea of Islam Nusantara, LGBT people, and Sharia regulation opponents, and claim that having more than one wife is improper teaching (Asyari \& Chandra 2019). He highlighted that this was a public policy aimed at preserving Muslims in West Sumatra, not political maneuvering (Asyari \& Chandra 2019). As a result, it is apparent that KH Ma'ruf Amin, as the chairman of the Central MUI, NU cadre, and Jokowi's vicepresidential candidate, is opposed against Buya Gusrizal Gazahar, as a representative of West Sumatra Province Ulama and MUI, ahead of the 2019 Presidential Election.

Religious issues are deliberately raised to generate polarization to mobilize voters based on religious issues and sentiments to support particular candidates. This phenomenon is in accordance with the findings of a study conducted by Onapajo (2016) religion is frequently used to organize voter support in elections by issuing religious issues in order to obtain an edge in general elections. As a result, voters will be divided on whether they support or oppose religious issues that are being debated. Guth et al. (2006) noted that political parties have used the subject of religion to galvanize voters to vote for their candidate. Raymond (2018) also discovered that when political parties purposefully raise the question of 
religion, it can lead to polarization among religious supporters. When political parties compete on issues relevant to religious voters who have organizational ties to religious groups in society, the polarization impact caused by religious concerns will intensify to the point where it determines the vote's outcome. Whitehead et al. (2018) revealed that the narrative on religious matters was purposefully raised to create religious sentiments in order to mobilize voters to maintain the hegemony of their religious sect by supporting certain presidential candidates.

\section{The Minang community supports Buya in rejecting religious issues ahead of the 2019 presidential election}

The majority of elements of the Minang community, West Sumatra support the buya's effort to reject Islam Nusantara and various other religious concerns that are not in conformity with the Islamic teachings adopted by the Minangkabau community. The buya resistance against Islam Nusantara also received support from various community leaders in West Sumatra (Saribundo 2018). In Bukittinggi City, during the series of Eid prayers, pamphlets were distributed to the congregation in a relay to the congregation stating that people there are together with the MUI of West Sumatra, opposing the concept of Islam Nusantara in Minangkabau (CNN Indonesia 2018). The community organization of Paga Nagari, West Sumatra, declared its opposition to Islam Nusantara and backed Buya Gazahar's position with all its body and soul because it was appropriate and consistent with the philosophy of life of the Minangkabau people. In fact, this mass organization is determined to expel outside parties in order to jeopardize the accord and the deliberation's outcomes, as well as belittling West Sumatran ulama as well as undertaking actions that pit the ulama and the Ummah against one another (Moeslimchoice.com 2018).

Public rejection of the issue of Islam Nusantara spread to the majority of elements of West Sumatran society. Among them in West Pasaman Regency, the community consisting of various community organizations and traditional leaders opposed the arrival of the Kirap Satu Negeri event for the Anshor Youth Movement and Banser NU to the area (Maulana 2018). The Regent of Tanah Datar, Irdinansyah Tarmizi, and the Mayor of Padang, Mahyeldi confirmed that they support the MUI of West Sumatra and reject the concept of Islam Nusantara (Kincai 2018, Putri 2018). Moreover, the worldwide association of Minangkabau migrants affirmed their support for Buya Gazahar and the MUI of West Sumatra. The buya's statement has represented all West Sumatran and Minangkabau immigrants from five continents steadfastly defended Buya Gusrizal Gazahar because the West Sumatran ulama are not ambitious for position and power, not betray the faith, and not support religious blasphemers (Afifi 2018).

The rejection of the concept of Islam Nusantara brought together all parts of society, including traditional and religious circles, just as when the two groups united against the Dutch in the Padri War in 1803-1838. In the Padri War, initially, there was a feud between religious groups and indigenous people from the Pagaruyung Kingdom in Tanah Datar due to differences in principles in the practice of Islam, but these two groups then realized that they had been pitted against the Dutch and eventually united against the Dutch (Welianto 2020). The union of the two groups was marked by the gathering of various elements of society at the Pagaruyung Palace in Tanah Datar on December 16, 2018, which was attended by Buya Gazahar as a religious community (MUI of West Sumatra), the Pagaruyung Kingdom, Chairman of Bundo Kanduang, Puti Reno Raudhatul Jannah Thaib, traditional leaders, various community organizations, institutions, and thousands of Tanah Datar communities. They reaffirmed the Bukit Marapalam Loyalty Oath (Sumpah Setia Bukit Marapalam) containing a statement of loyalty from various elements of society to enforce Islamic law in Minangkabau, reject the concept of Islam Nusantara in Minang Land, reject Lesbian, Gay, and Trans Gender, and other notion that destroys Islam (Gosumbar 2018, Pasbana. com 2018). The union of religious communities, indigenous peoples, and various other elements of society has demonstrated that the majority of Minang people reject the Islam Nusantara concept which is associated with the Jokowi-Ma'ruf Amin pair to be elected in the 2019 Presidential Election.

The Presidential Election results in West Sumatra, which showed Jokowi's vote acquisition was decreasing in this province was related to the idea of Islam Nusantara which was contrary to the 
wishes of the Minang people. Some experts projected that Jokowi-Ma'ruf would lose heavily in the 2019 Presidential Election in West Sumatra, including Asrinaldi, an observer at Andalas University, who indicated that Jokowi's followers' opinions or thoughts about religion generated public hostility to vote for Jokowi (Rika 2019). Adi Prayitno, a political observer at UIN Hidayatullah Jakarta, argued that Jokowi's defeat in West Sumatra is due to the sociological and emotional nature of the people in this area, who use religion as the main tool of political preference. For the majority of voters in West Sumatra, Jokowi seems to have a distance from Muslim society (Ristianto \& Asril 2019).

This phenomenon is consistent with the findings of a study conducted by Akinloye (2018) that religious leaders have a strong influence on their followers and are found to often become political actors by bringing up religious issues as the major issue in elections. Raymond (2018) claimed that the polarization effect due to religious issues will strengthen so that it determines the voting results. According to BarrettFox (2018), Religion issues are being utilized to encourage voters to defend their religious beliefs against attacks from other parties. Torgler et al. (2013) discovered that religious leaders' recommendations were able to influence their congregations' political decisions, which had an impact on their sect. According to Jeppsonn (2018), the issue of religion for some voters remains a voter preference in making political choices. Guth et al. (2005) discovered that religious factors influence election outcomes far more than gender and other factors.

\section{Conclusion}

The decline in Jokowi's vote acquisition in West Sumatra in the 2019 Presidential Election cannot be separated from the influence of buya and emerging religious issues as well as the characteristics of the Muslims who had the voting rights in the area. In the West Sumatra region, the ulama, understanding, and sects that are developing are Modern Islam, which is distinct from that of Jokowi's vice-presidential candidate, Ma'ruf Amin, who adheres to traditional Islam, NU. Buya Gazahar's position, supported by other buya in West Sumatra, contradicts Ma'ruf Amin's and his followers' positions on the topics of Islam Nusantara and the Sharia Regional Regulations.

The reality reveals that voters in West Sumatra can be mobilized to support other candidates than JokowiMa'ruf utilizing religious issues, aiming of protecting the religious life of West Sumatras from threats from other understandings. The majority of people followed Buya's direction in voting in the 2019 Presidential Election by making religious issues a preferred matter in the Presidential Election. This has an impact on the movement of some Jokowi's votes to the Prabowo-Sandi pair in the 2019 Presidential Election in West Sumatra.

\section{References}

Afifi WA (2018) Perantau Minangkabau sedunia tegaskan tolak Islam Nusantara. Sumbarsatucom, 01 August. [Accessed 20 October 2021]. https://sumbarsatu.com/berita/18844-perantauminangkabau-sedunia-tegaskan-tolak-islam-nusantara.

Agbor UJ (2019) Religion as a determinant of voter behavior: An analysis of the relation between religious inclination and voting pattern in cross river state, Nigeria. Journal of Social Science Research 14:3252-3267. https://doi.org/10.24297/jssr.v14i0.8357.

Akinloye IA (2018) Towards the implementation of sustainable development goals in Nigeria: Maximizing the influence of religious leaders. Stellenbosch Theological Journal 4 (1):39-60. https://doi.org/10.17570/stj.2018.v4n1.a02.

Alava H \& Ssentongo JS (2016) Religious (de) politicization in Uganda's 2016 elections. Journal of Eastern African Studies 10 (4):677-692. https://doi.org/10.1080/17531055.2016.1270043.

Alfons M (2018) Ma'ruf Amin: Islamnya MUI itu Islam Nusantara, Islam berkemajuan. DetikNews, 26 July. [Accessed 03 August 2020]. https://news.detik.com/berita/d-4135579/maruf-aminislamnya-mui-itu-islam-nusantara-islam-berkemajuan. 
As'ad M (2011) Official Ulama in Indonesian Politics: Study on the Attitudes of the Indonesian Council of Ulama in the General Elections. In: International Conference Is Indonesian Islam different? Islam in Indonesia in an international comparative perspective held by Leiden University in cooperation with PPIM, UIN Syarif Hidayatullah, 24-26 January, Jakarta.

Ashsubli M, Kartini DS, \& Paskarina C (2021) Politics and religion (study of the effect made by Ustadz Abdul Somad on the 2019 presidential election in Riau Province). Journal of Hunan University (Natural Sciences) 48 (9):425-436.

Astungkoro R \& Saubani A (2019) Survei: FPI dan Alkhairaat solid dukung Prabowo-Sandi. Republika, 14 March. [Accessed 03 August 2020]. https://nasional.republika.co.id/berita/nasional/politik/ pobbei409/survei-fpi-dan-alkhairaat-solid-dukung-prabowosandi.

Asyari Y \& Chandra R (2019) Tegas! Ini arah Politik Ketua MUI Sumbar. Jawa Pos, 08 February. [Accessed 01 Agustus 2020]. https://www.jawapos.com/jpg-today/08/02/2019/tegas-ini-arahpolitik-ketua-mui-sumbar/.

Bahtiar A (2019) Pengaruh Syekh Ahmad Khatib al-Minangkabawi terhadap dinamika intelektual Islam di Indonesia 1900-1947 M. Thesis, UIN Sunan Ampel, Surabaya.

Barrett-Fox R (2018) A king cyrus president: How Donald Trump's presidency reasserts conservative christians' right to hegemony. Humanity \& Society 42 (4):502-522. https://doi. org/10.1177/0160597618802644.

Bentengsumbar (2017) Bachtiar Nasir katakan Jokowi menilai tidak ada upaya mengkasuskan ulama. Bentengsumbar, 28 June. [Accessed 27 July 2020]. https://www.bentengsumbar.com/2017/06/ bachtiar-nasir-sebut-presiden-jokowi.html.

Bøås M, Cissé AW, \& Diallo A (2019) Mali's Religious Leaders and the 2018 Presidential Elections. Oslo: Norwegian Institue of International Affairs.

Cahyono S (2018) MUI Sumbar komitmen tolak Islam Nusantara. Jawa Pos, 26 July. [Accessed 01 August 2020]. https://www.jawapos.com/jpg-today/26/07/2018/mui-sumbar-komitmen-tolakislam-nusantara/.

CNN Indonesia (2018) Pamflet tolak Islam Nusantara disebar ke jemaah Bukittinggi. CNN Indonesia, 22 August. [Accessed 27 July 2020]. https://www.cnnindonesia.com/ nasional/20180822082320-20-324082/pamflet-tolak-islam-nusantara-disebar-ke-jemaahbukittinggi.

CNN Indonesia (2019) Ahok sang pemicu rentetan aksi bela Islam dan nama besar 212. CNN Indonesia, 22 January. [Accessed 27 July 2020]. https://www.cnnindonesia.com/ nasional/20190115135955-32-360979/ahok-sang-pemicu-rentetan-aksi-bela-islam-dan-namabesar-212.

Dahono Y (2018) Ma'ruf Amin siap gaungkan Islam Nusantara dan berkemajuan. Berita Satu, 15 October. [Accessed 27 July 2020]. https://www.beritasatu.com/politik/516682/maruf-amin-siapgaungkan-islam-nusantara-dan-berkemajuan.

Damarjati D (2018) MUI Sumatra Barat tolak 'Islam Nusantara'. Detiknews, 25 July. [Accessed 01 January 2022]. https://news.detik.com/berita/d-4133086/mui-sumatra-barat-tolak-islamnusantara.

Detiknews (2009) Jeffrie dan Nudirman masuk Senayan, Indra Pilliang gagal. Detiknews, 26 April. [Accessed 03 August 2020]. https://news.detik.com/pemilu/d-1121667/jeffrie-dan-nudirmanmasuk-senayan-indra-pilliang-gagal.

Ditpolkom Bappenas (2009) Hasil perolehan suara peserta pemilu tahun 2009 partai politik (DPR RI) Provinsi Sumatra Barat [Accessed 01 January 2022]. http://ditpolkom.bappenas.go.id/ basedir/Politik\%20Dalam\%20Negeri/1)\%20Pemilu/4)\%20Pemilu\%20tahun\%202009/ PEMILU/Hasil\%20perolehan\%20Suara\%20Partai\%20Politik\%20Perpropinsi/31.\%20Hasil\%20 perolehan\%20Suara\%20Partai\%20Politik\%20sumbar.pdf.

Erman E (2015) Perlawanan ulama Minangkabau terhadap kebijakan kolonial di bidang pendidikan awal abad XX. Turast: Jurnal Penelitian dan Pengabdian 3 (1):1-21. https://doi.org/10.15548/ turast.v3i1.372.

Freedman M (2020) Vote with your rabbi: The electoral effects of religious institutions in Israel. Electoral Studies 68. https://doi.org/10.1016/j.electstud.2020.102241. 
Goldberg AC (2014) The impact of religion on voting behaviour - a multilevel approach for Switzerland. Swiss Political Science Review 20 (2):305-329. https://doi.org/10.1111/spsr.12068.

Gosumbar (2018) Sumpah Sati Bukik Marapalam kembali dikukuhkan, syariat Islam harus tetap membumi di Ranah Minang. GoSumbar.com, 17 Decermber. [Accessed 17 December 2020]. https://www.gosumbar.com/berita/baca/2018/12/17/sumpah-sati-bukik-marapalam-kembalidikukuhkan-syariat-islam-harus-tetap-membumi-di-ranah-minang.

Guth JL, Kellstedt LA, Smidt CE, \& Green JC (2005) Religious Mobilization in the 2004 Presidential Election. Washington DC: American Political Science Association.

Guth JL, Kellstedt LA, Smidt CE, \& Green JC (2006) Religious influences in the 2004 presidential election. Presidential Studies Quarterly 36 (2):223-242. https://doi.org/10.1111/j.1741-5705.2006.00300.

Hakim RN (2019) Suara Jokowi vs Prabowo per propinsi di pilpres 2014 dan 2019. Kompas.com, 21 May. [Accessed 01 August 2020]. https://nasional.kompas.com/read/2019/05/21/20014871/ suara-jokowi-vs-prabowo-per-provinsi-di-pilpres-2014-dan-2019? page=all.

Hasan AM (2018) Peraturan daaerah syariah: dagangan isu petinggi parpol tertentu. Tirto.id, 21 November. [Accessed 26 July 2020]. https://irto.id/perda-syariah-jualan-elite-politik-daganganpartai-sekuler-dajm.

Hospita W, Zetra A, \& Afrizal (2018) Framing gerakan forum masyarakat Minangkabau dan advokasi kebijakan investasi di Kota Padang: Kasus PT. Lippo Tbk. Kelola: Jurnal Sosial Politik 1 (1):5769. https://doi.org/10.15575/jk.v1i1.3768.

Imadudin I (2005) "New Sufism": Kebangkitan "Islam Tradisi” di Minangkabau. In: 4th International Symposium of the Journal Antropologi Indonesia, 12-15 July, Depok. 4th International Symposium. 1-13.

Jeppsson E (2018) Persistence and Strength of the Religious Cleavage in Sweden: (De) Alignment in a Secularized and Post-Modern Nation, 1986-2016. Goteborg: Goteborgs Universitet.

Kincai RD (2018) Bupati Irdinansyah Tarmizi, tak izinkan seminar Islam Nusantara di Kab. Tanah Datar. Portal Berita Editor, 06 August. [Accessed 01 January 2022]. https://www.portalberitaeditor. com/bupati-irdinansyah-tarmizi-tak-izinkan-seminar-islam-nusantara-di-kab-tanah-datar/.

KPU (2009) Daftar calon terpilih anggota Dewan Perwakilan Rakyat Republik Indonesia hasil Pemilu tahun 2009. [Accessed 01 January 2022]. https://www.kpu.go.id/dmdocuments/DAFTAR_ ANGGOTA_DPR_2009.pdf.

Kumparan News (2019) 14 caleg DPR terpilih Sumbar: Andre Rosiade hingga Mulyadi. Kumparan. com, 15 May. [Accessed 01 August 2020]. https://kumparan.com/kumparannews/14-caleg-dprterpilih-sumbar-andre-rosiade-hingga-mulyadi-1r5GoIEC1yV/full.

Lazuardi G (2019) 10 alasan Rizieq Shihab dukung Prabowo-Sandi, di antaranya menentang kriminalisasi terhadap ulama. Tribunnews.com, 07 April. [Accessed 09 August 2020]. https://www.tribunnews. com/pilpres-2019/2019/04/07/10-alasan-rizieq-shihab-dukung-prabowo-sandi.

Makhasin L (2017) Islamic organisation and electoral politics: Nahdlatul Ulama and Islamic mobilisation in an Indonesian local. PCD Journal 5 (2):323-352. https://doi.org/10.22146/pcd.29318.

Maulana A (2018) Organisasi masyarakat Pasaman Barat menolak datangnya kirap Islam Nusantara. Antara Sumbar, 23 September. [Accessed 23 September 2020]. https://sumbar.antaranews.com/ berita/233324/organisasi-masyarakat-pasaman-barat-tolak-kedatangan-kirap-islam-nusantara.

Moeslimchoice (2018) Paga Nagari minta Din Syamsuddin tarik statementnya. Moeslimchoice.com, 31 July. [Accessed 31 July 2020]. https://www.moeslimchoice.com/read/2018/07/31/12450/paganagari-minta-din-syamsuddin-cabut-pernyataan.

Nathaniel F (2019) Waketum MUI: Pernyataan ketua MUI Sumbar bukan sikap lembaga. Tirto.id, 19 November. [Accessed 26 July 2020]. https://tirto.id/waketum-mui-pernyataan-ketua-mui-sumbarbukan-sikap-lembaga-dagq.

Noeh MF \& Othman MR (2012) The role of Kiai in the 2004 presidential election: A case study in East Java. Sarjana 27 (2):131-146.

Noer D (1996) Gerakan Moderen Islam di Indonesia 1900-1942. Jakarta: LP3ES.

Nubowo A (2020) Analisis pilpres 2019: Pengaruh hebat Islam dalam politik Indonesia. Matamata Politik, 12 December. [Accessed 26 July 2021]. https://www.matamatapolitik.com/news/analisispilpres-2019-pengaruh-hebat-islam-dalam-politik-indonesia. 
Nurita D (2018) PSI terima semua konsekuensi logis sikap menolak perda syariah. Tempo.co, 21 November. [Accessed 01 August 2020]. https://nasional.tempo.co/read/1148234/psi-terimasemua-konsekuensi-logis-sikap-menolak-perda-syariah.

Oktara A (2015) Politik Tuan Guru di Nusa Tenggara Barat. Government: Jurnal Ilmu Pemerintahan 8 (2):73-82.

Onapajo H (2016) Politics and the pulpit: The rise and decline of religion in Nigeria's 2015 Presidential elections. Journal of African Elections 15 (2):136-158. https://doi.org/10.20940/JAE/2016/v15i.

Pasbana.com (2018) Senada dengan MUI Sumbar, Bundo Kandung juga tolak isnus di Sumbar. Pasbana. com, 31 July. [Accessed 01 Agustus 2020]. https://www.pasbana.com/2018/07/senada-denganmui-sumbar-bundo-kandung.html.

Pemilu Asia (2009) Pemilu DPR 1955 Sumatra Tengah. [Accessed 27 July 2020]. http://www.pemilu.as ia/?lang=ind $\& \mathrm{c}=54 \&$ opt $=1 \& \mathrm{~s}=44 \& \mathrm{id}=12$.

Pisani E \& Buehler M (2016) Why do Indonesian politicians promoteshari'alaws? An analytic framework for Muslim-majority democracies. Third World Quarterly 38 (3):734-752. https://doi.org/10.108 0/01436597.2016.1206453.

Prasetia A (2018) Ma'ruf Amin: Islam Nusantara bagian dari RI, MUI tak boleh mencela. Detiknews, 26 July. [Accessed 03 August 2020]. https://news.detik.com/berita/d-4134757/maruf-aminislam-nusantara-bagian-dari-ri-mui-tak-boleh-mencela\#: : text=detikNews\%20Berita,Ma\%27ruf\%20Amin\%3A\%20Islam\%20Nusantara\%20Bagian\%20dari,RI\%2C\%20MUI\%20 Tak\%20Boleh\%20Mencela\&text=Jakarta\%20\%2D\%20Majelis\%20Ulama\%20Indonesia\%20 (MUI,boleh\%20mencela\%20salah\%20satu\%20aliran.

Priatmojo D \& Sadat A (2018) Ijtima ulama dukung Prabowo-Sandi, kubu Jokowi-Ma'ruf dinilai panik. Viva.co.id, 17 September. [Accessed 26 July 2020]. https://www.viva.co.id/berita/ politik/1075461-ijtima-ulama-dukung-prabowo-sandi-kubu-jokowi-ma-ruf-dinilai-panik.

Putra P (2019) Sosialisasi gencar, Jokowi-Ma'ruf justru kalah telak di Sumbar, kenapa? Kompas.com, 13 May. [Accessed 10 August 2020]. https://regional.kompas.com/read/2019/05/13/09541021/ sosialisasi-gencar-jokowi-maruf-justru-kalah-telak-di-sumbar-kenapa.

Putri ZA (2018) MUI Sumbar tolak Islam Nusantara, ini kata MUI Pusat. Detiknews, 25 July. [Accessed 10 August 2021]. https://news.detik.com/berita/d-4133174/mui-sumbar-tolak-islam-nusantaraini-kata-mui-pusat.

Ranahberita.com (2013) Tradisi perolehan kursi DPR di Sumbar dalam 3 pemilu terakhir. Ranahberita. com, 07 May. [Accessed 03 August 2020]. http://www.news.ranahweb.com/news.php?id_ news=193/Kotak-Suara/view/Tradisi-Perolehan-Kursi-DPR-di-Sumbar-dalam-Tiga-PemiluTerakhir\&kategori=Kotak\%20Suara\#.Yc1UBWBBzIU.

Raymond CD (2018) Electoral Choice and Religion: An Overview. Oxford Research Encyclopedia of Politics. https://doi.org/10.1093/acrefore/9780190228637.013.672.

Razzaq A (2014) Dinamika dakwah dan politik dalam pemikiran Islam modernis Di Indonesia. Wardah 15 (1):7-15. https://doi.org/10.19109/wardah.v15i1.202.

Riana F \& Chairunnisa N (2018) Solidaritas Alumni 212 minta Jokowi stop kriminalisasi ulama. Tempo. co, 20 January. [Accessed 03 August 2020]. https://nasional.tempo.co/read/1052375/solidaritasalumni-212-minta-jokowi-stop-kriminalisasi-ulama.

Rika H (2019) Menakar kekalahan telak Jokowi dari Prabowo di Sumatra Barat. CNN Indonesia, 23 April. [Accessed 20 October 2021]. https://www.cnnindonesia.com/ nasional/20190423074454-32-388689/menakar-kekalahan-telak-jokowi-dari-prabowo-disumatra-barat.

Ristianto C \& Asril S (2019) Kalah telak di Sumbar, prestasi Jokowi tak mampu luluhkan politik identitas. Kompas.com, 13 May. [Accessed 20 October 2021]. https://nasional.kompas.com/ $\mathrm{read} / 2019 / 05 / 13 / 12132811 /$ kalah-telak-di-sumbar-prestasi-jokowi-tak-mampu-luluhkan-politikidentitas.

Sani AFI \& Hantoro J (2019) Jokowi: Tunjukan ulama mana yang di kriminalisasi, saya urus. Tempo. co, 18 February. [Accessed 27 July 2020]. https://nasional.tempo.co/read/1176993/jokowitunjukkan-ulama-mana-yang-dikriminalisasi-saya-urus. 
Saputra A (2019) Tak dapat kursi DPR dari Sumbar, PDIP gugat ke MK. Detiknews, 30 May. [Accessed 3 August 2020]. https://news.detik.com/berita/d-4570549/tak-dapat-kursi-dpr-dari-sumbar-pdipgugat-ke-mk.

Saputra R \& Alfath A (2017) Soal Habib Rizieq, JK diminta nasehati Jokowi. Viva.co.id, 31 May. [Accessed 26 July 2020]. https://www.viva.co.id/berita/nasional/921300-soal-habib-rizieq-jkdiminta-nasehati-jokowi.

Saputro A (2018) Agama dan negara: Politik identitas menuju pilpres 2019. Asketik 2 (2):111-120.

Saribundo (2018) Ulama Minang kokoh jaga Sumbar dan tolak konsep Islam Nusantara. [Accessed 18 August 2020] https://www.saribundo.biz/ulama-minang-kokoh-jaga-sumbar-dan-tolak-konsepislam-nusantara.html.

Sanusi A \& Gumilar G (2019) Peran Ma'ruf Amin dalam meraih suara masyarakat Muslim pada pemilihan presiden 2019. Lentera 3 (1):65-81. https://doi.org/10.21093/lentera.v3i1.1407.

Schliesser C (2020) Religion and peace-anatomy of a love-hate relationship. Religions 11 (5):1-12. https://doi.org/10.3390/rel11050219.

Siregar R (2019) Diskriminasi ulama dan pemuka agama picu perlawanan umat. Sindonews.com, 10 January. [Accessed 01 August 2020]. https://nasional.sindonews.com/berita/1369217/12/ diskriminasi-ulama-dan-pemuka-agama-picu-perlawanan-umat.

Sonhaji M \& Maulida FH (2020) Komunikasi Politik dan kecenderungan pilihan partai kaum santri dan abangan pada pemilu 1955. Nyimak: Journal of Communication 4 (1):109-124.

Sujono I (2021) Riyanto dan bom Natal 2000: Nalar Banser NU dalam nestapa ketahanan toleransi beragama di Indonesia. Jurnal Islam Nusantara 5 (1):38-51. https://doi.org/10.33852/jurnalnu. v5i1.228.

Sumbarfokus (2018) 2.000 Relawan akan deklarasi menangi Prabowo-Sandi di Sumbar. Sumbarfokus. com, 24 September. [Accessed 26 July 2020]. https://www.sumbarfokus.com/berita-2000relawan-akan-deklarasi-menangi-prabowosandi-di-sumbar.html.

Suriyanto (2015) Muktamar NU: Antara Islam Nusantara dan peradaban dunia. CNN Indonesia, 30 July. [Accessed01 January2022].https://www.cnnindonesia.com/nasional/20150730142952-20-69107/ muktamar-nu-antara-islam-nusantara-dan-peradaban-dunia.

Suryani D (2014) Di Dapil Sumbar I, 8 kursi DPR RI dibagi rata delapan parpol. [Accessed 23 September 2020]. https://sumbarprov.go.id/home/news/2298-di-dapil-sumbar-i-8-kursi-dpr-ri-dibagi-ratadelapan-parpol.html.

Suwarno (2019) Kelahiran Muhammadiyah dari perspektif hermeneutik. Sasdaya: Gajahmada Journal of Humanities 3 (1):45-60.

Temby Q (2019) Disinformation, violence, and anti-Chinese sentiment in Indonesia's 2019 elections. Researchers at Iseas - Yusof Ishak Institute Analyse Current Events, 1-8.

Tempo (2011) Dua wajah aturan syariah. Tempo, 29 August. [Accessed 09 August 2020]. https://majalah. tempo.co/read/laporan-utama/137629/dua-wajah-aturan-syariah.

Thalib A (2018) Pertarungan ulama sana versus ulama sini. Geotimes, 2 September. [Accessed 26 July 2020]. https://geotimes.id/opini/pertarungan-ulama-sana-versus-ulama-sini/.

Thomas J \& Harden A (2008) Methods for the thematic synthesis of qualitative research in systematic reviews. BMC Medical Research Methodology 8 (1):1-10. https://doi.org/10.1186/1471-2288-845.

Torgler B, Stadelmann D, \& Portmann M (2013) The power of religious organizations in human decision processes: Analyzing voting behavior. CREMA Working Paper Series 2013-20, Center for Research in Economics, Management and the Arts (CREMA).

Wanto A (2020) Analisa pemilihan presiden 2019: Mengapa Jokowi berpotensi kalah di Sumbar. Matamata Politik, 12 December. [Accessed 26 July 2021]. https://www.matamatapolitik.com/ news/analisis-pilpres-2019-mengapa-jokowi-berpotensi-kalah-di-sumbar.

Welianto A (2020) Perang Padri, Perang saudara yang berubah melawan Belanda. Kompas.com, 20 May. [Accessed 20 May 2021]. https://www.kompas.com/skola/read/2020/05/20/184500569/ perang-padri-perang-saudara-yang-berubah-melawan-belanda?page=all\#: :text=KOMPAS . com $\% 20 \% 2 \mathrm{D} \% 20$ Perang $\% 20$ Padri $\% 20$ merupakan,Kerajaan $\% 20$ Pagaruyung $\% 20$ pada $\% 20$ $1803 \% 2 \mathrm{D} 1838$. 
Whitehead AL, Perry SL, \& Baker JO (2018) Make America Christian Again: Christian nationalism and voting for Donald Trump in the 2016 presidential election. Sociology of Religion: A Quarterly Review 79 (2):147-171.

Winarni L (2014) The political identity of ulama in the 2014 Indonesian presidential election. Al-Jami'ah 52 (2):257-269. https://doi.org/10.14421/ajis.2014.522.257-269.

Zulfadli \& Arrasuli BK (2017) Kuasa ormas di Ranah Minang: Penolakan ormas keagamaan terhadap pembangunan Rumah Sakit Siloam di Kota Padang. Sosial Budaya 14 (1):35-54. https://doi. org/10.24014/sb.v14i1.4161. 